\title{
From ice-shelf tributary to tidewater glacier: continued rapid recession, acceleration and thinning of Röhss Glacier following the 1995 collapse of the Prince Gustav Ice Shelf, Antarctic Peninsula
}

\author{
N.F. GLASSER, ${ }^{1}$ T.A. SCAMBOS, ${ }^{2}$ J. BOHLANDER, ${ }^{2}$ M. TRUFFER, ${ }^{3}$ E. PETTIT, ${ }^{4}$ \\ B.J. DAVIES ${ }^{1}$ \\ ${ }^{1}$ Centre for Glaciology, Institute of Geography and Earth Sciences, Aberystwyth University, Aberystwyth SY23 3DB, UK \\ E-mail: nfg@aber.ac.uk \\ ${ }^{2}$ National Snow and Ice Data Center, 1540 30th Street, CIRES, Campus Box 449, University of Colorado, \\ Boulder, Colorado 80309-0449, USA \\ ${ }^{3}$ Geophysical Institute, University of Alaska Fairbanks, PO Box 757320, Fairbanks, Alaska 99775-7320, USA \\ ${ }^{4}$ Department of Geology and Geophysics, University of Alaska Fairbanks, PO Box 755780, \\ Fairbanks, Alaska 99775-5780, USA
}

\begin{abstract}
We use optical (ASTER and Landsat) and radar (ERS-1 and ERS-2) satellite imagery to document changes in the Prince Gustav Ice Shelf, Antarctic Peninsula, and its tributary glaciers before and after its January 1995 collapse. The satellite image record captures the transition from an ice-shelf glacier system to a tidewater glacial system and the subsequent rapid retreat and inferred 'fatal' negative mass balances that occur as lower glacier elevations lead to higher ablation and tidewater-style calving collapse. Pre-1995 images show that the central ice shelf was fed primarily by Siögren Glacier flowing from the Antarctic Peninsula and by Röhss Glacier flowing from James Ross Island. Numerous structural discontinuities (rifts and crevasses) and melt ponds were present on the ice shelf before the collapse. After the ice shelf collapsed, Röhss Glacier retreated rapidly, becoming a tidewater glacier in 2002 and receding a total of $\sim 15 \mathrm{~km}$ between January 2001 and March 2009, losing $>70 \%$ of its area. Topographic profiles of Röhss Glacier from ASTER-derived digital elevation models show a thinning of up to $\sim 150 \mathrm{~m}$, and surface speeds increased up to ninefold $\left(0.1-0.9 \mathrm{~m} \mathrm{~d}^{-1}\right)$ over the same period. The rates of speed increase and elevation loss, however, are not monotonic; both rates slowed between late 2002 and 2005 , accelerated in 2006 and slowed again in 2008-09. We conclude that tributary glaciers react to ice-shelf removal by rapid (if discontinuous) recession, and that the response of tidewater glaciers on the Antarctic Peninsula to ice-shelf removal occurs over timescales ranging from sub-annual to decadal.
\end{abstract}

\section{INTRODUCTION}

The recent retreat of Antarctic Peninsula ice shelves has been variously attributed to atmospheric warming (Vaughan and Doake, 1996; Rott and others, 1998; Scambos and others, 2000, 2003; Van den Broeke, 2005) or oceanographic changes (Shepherd and others, 2003), either of which can lead to changes in ice-shelf structural composition (Glasser and Scambos, 2008; Humbert and Braun, 2008; Glasser and others, 2009; Humbert and others, 2009; Scambos and others, 2009). Antarctic Peninsula ice shelves have retreated dramatically to the extent that some ice shelves have completely disintegrated (Doake and Vaughan, 1991; Rott and others, 2002; Scambos and others, 2003; Glasser and Scambos, 2008; Cook and Vaughan, 2010). Ice shelves that have collapsed around the Antarctic Peninsula ('disintegration events' as described by Scambos and others, 2009) include the Larsen A and Prince Gustav ice shelves in January 1995 (combined area $2030 \mathrm{~km}^{2}$ ), the partial collapse of the Wilkins Ice Shelf in March $1998\left(1100 \mathrm{~km}^{2}\right)$, March 2008 $\left(405 \mathrm{~km}^{2}\right)$, May $2008\left(160 \mathrm{~km}^{2}\right)$, April $2009\left(700 \mathrm{~km}^{2}\right)$ and June-July $2009\left(1220 \mathrm{~km}^{2}\right)$ and the Larsen B ice shelf in February-March $2002\left(3200 \mathrm{~km}^{2}\right)$. In most cases, substantial change in ice-shelf extent occurred in short periods of time. For example, the Larsen B ice shelf (Fig. 1a) lost 19.6\% of its area in a single iceberg-calving-plus-disintegration event in January 1995 (Rack and others, 2000).
Remotely sensed and modeled glacier speed and elevation measurements have revealed that ice-shelf removal leads to the thinning and acceleration of tributary glaciers (Thomas and others, 1979; De Angelis and Skvarca, 2003; Rignot and others, 2004; Scambos and others, 2004; Pritchard and Vaughan, 2007; Hulbe and others, 2008). The physical process behind this observation is that the presence of an ice shelf reduces longitudinal stresses and therefore limits glacier motion upstream of the ice shelf. Once the ice shelf is removed, the tributary glaciers accelerate and thin. The loss of floating tongues and retreat of grounding lines has also led to a doubling of flow speeds at many outlet glaciers in Greenland (e.g. Joughin and others, 2004; Luckman and others, 2006; Howat and others, 2008). Cook and others (2005) determined that $87 \%$ of Antarctic Peninsula glaciers are in recession, and Rignot and others (2005) estimated that the recent annual mass loss from the glaciers of the northern Antarctic Peninsula is sufficient to raise eustatic sea level by $0.1 \mathrm{mma}^{-1}\left(36 \mathrm{Gta}^{-1}\right)$. This is consistent with recent estimates of mass loss in the northern peninsula from changes in the gravitational field (Chen and others, 2009).

In this paper, we build on these previous remotely sensed observations of glacier acceleration and elevation lowering by examining the response of contributing glaciers from James Ross Island and the Antarctic Peninsula after the 1995 


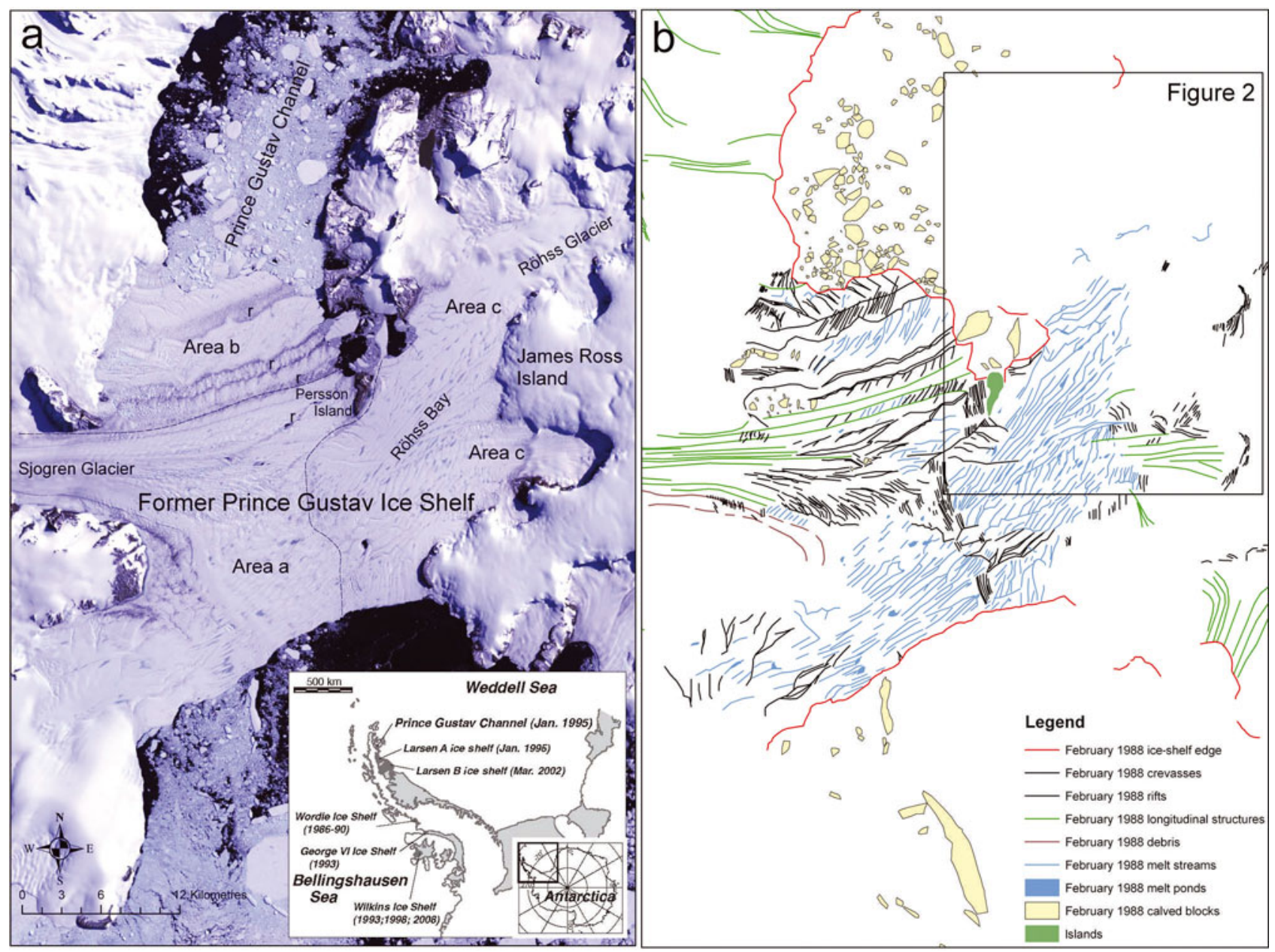

Fig. 1. (a). Portion of Landsat 4/5 TM image of the Prince Gustav Ice Shelf (PGIS), Antarctic Peninsula, acquired on 29 February 1988. Areas identified as Areas a-c, separated by dashed lines, refer to flow units and areas of the ice shelf discussed in the text. Areas marked ' $r$ ' at the northern edge of the ice shelf indicate prominent rifts with disaggregated glacier blocks. Inset shows the location of James Ross Island and the PGIS. (b) Structural glaciological interpretation of the PGIS based on the same Landsat 4/5 TM image. The box indicates the area depicted in Figure 2.

collapse of the Prince Gustav Ice Shelf (PGIS; Fig. 1a). We do this by first presenting a structural glaciological interpretation of the ice shelf and its tributary glaciers prior to its collapse and then by presenting a sequence of interpreted satellite images covering the longer-term response of its tributary glaciers. For the main tributary, Röhss Glacier, we also present ice surface elevation changes derived from Advanced Spaceborne Thermal Emission and Reflection Radiometer (ASTER) digital elevation models (DEMs) and changes in surface speed from feature tracking on ASTER images. These data demonstrate that, in addition to large and rapid short-term acceleration and thinning after ice-shelf loss, tributary glaciers continue to react to ice-shelf removal for as many as 15 years. Between January 2001 and March 2009 (6-14 years after collapse), the front of Röhss Glacier receded a total of $\sim 15 \mathrm{~km}$ and lost $>70 \%$ of its area.

\section{DATA AND METHODS}

\section{Satellite image interpretation and structural glaciology}

Glacier recession in the area covered by the former PGIS was mapped from optical satellite imagery using a series of Terra ASTER (horizontal resolution $15 \mathrm{~m}$ ) and Landsat 4/5 thematic mapper (TM) (horizontal resolution $30 \mathrm{~m}$ ) georectified images in ArcMap Geographical Information System (GIS) software (Table 1). We also used radar images from European Remote-sensing Satellites (ERS-1 and ERS-2; horizontal resolution $25 \mathrm{~m}$ ) from 1992, 1995 and 1998 to map recession of the PGIS. Satellite image interpretation was performed using multiple band combinations and standard image enhancement procedures (contrast stretching and histogram equalization) to improve contrast and enhance small-scale features. Features were mapped and digitized on-screen from the satellite images. Mapped features include ice-shelf/glacier extent, crevasses and rifts, surface debris, longitudinal surface structures, icebergs, melt streams and melt ponds. All mapping was carried out at $1: 50000$ scale.

\section{Surface elevation changes}

To estimate surface elevation changes of Röhss Glacier during the study period, we used eight ASTER DEMs derived from satellite stereo image pairs provided by the Land Processes Distributed Active Archive Center (LP DAAC; Table 1 and https://wist.echo.nasa.gov/ wist/api/ imswelcome/). These DEMs are produced without ground control, and therefore can have vertical offsets of up to $50 \mathrm{~m}$. We selected the best of the ASTER DEMs in our image set 
Table 1. Remotely sensed data sources used in this study

\begin{tabular}{|c|c|c|c|c|}
\hline Date & Sensor & Scene ID & Centre & DEM, VEL* \\
\hline 1 Feb 1977 & Landsat $1 / 2 \mathrm{MSS}^{\dagger}$ & Path 230, row 105 and path 230, row 106 & $64.419^{\circ} \mathrm{S}, 58.132^{\circ} \mathrm{W}$ & \\
\hline 29 Feb 1988 & Landsat 4 TM & LT42151051988060XXX11 & $64.208^{\circ} \mathrm{S}, 57.131^{\circ} \mathrm{W}$ & \\
\hline 9 Feb 1990 & Landsat $4 \mathrm{TM}$ & LT42161051990040XXX01 & $64.301^{\circ} \mathrm{S}, 57.000^{\circ} \mathrm{W}$ & \\
\hline 18 July 1992 & ERS-1 & Orbit 5264, frame 4932, track 109 & $64.261^{\circ} \mathrm{S}, 58.220^{\circ} \mathrm{W}$ & \\
\hline 30 Jan 1995 & ERS-1 & Orbit 18532, frame 4928, track 1731 & $64.173^{\circ} \mathrm{S}, 58.813^{\circ} \mathrm{W}$ & \\
\hline 8 Jan 2001 & ASTER & AST_L1B00301082001131449 AST_L1A0032004102903 & $64.120^{\circ} \mathrm{S}, 57.690^{\circ} \mathrm{W}$ & $\mathrm{D}, \mathrm{P} 1$ \\
\hline 18 Jan 2002 & ASTER & AST_L1B00301182002131108 AST_L1A0032005839335 & $64.234^{\circ} \mathrm{S}, 58.520^{\circ} \mathrm{W}$ & $\mathrm{D}, \mathrm{P} 1, \mathrm{P} 2$ \\
\hline 29 Dec 2002 & ASTER & AST_L1B00312292002130340 AST_L1A0032010352317 & $64.116^{\circ} \mathrm{S}, 57.799^{\circ} \mathrm{W}$ & D. P2, P3 \\
\hline 2 Feb 2004 & ASTER & AST_L1B00302022004130313 AST_L1A0032020410756 & $64.097^{\circ} \mathrm{S}, 57.825^{\circ} \mathrm{W}$ & $\mathrm{D}, \mathrm{P} 3, \mathrm{P} 4$ \\
\hline 10 Nov 2005 & ASTER & AST_L1B00311102005130754 AST_L1A0032031685142 & $64.192^{\circ} \mathrm{S}, 58.662^{\circ} \mathrm{W}$ & D, P4, P5 \\
\hline 23 Feb 2006 & ASTER & AST_L1B00302232006130133 AST_L1A0032033215252 & $64.112^{\circ} \mathrm{S}, 57.739^{\circ} \mathrm{W}$ & D, P5 \\
\hline 8 Dec 2006 & ASTER & AST_L1B00312082006130157 AST_L1A0032039095257 & $64.118^{\circ} \mathrm{S}, 57.759^{\circ} \mathrm{W}$ & \\
\hline
\end{tabular}

*D refers to stereo satellite DEM used in Figure 6a; P1, P2, etc. refer to image pairs for ice velocity measurement in Figure $6 b$ and c.

${ }^{\dagger}$ Multispectral scanner.

(23 February 2006) based on its lower noise, regionally continuous coverage, and near-zero elevation over sea-ice areas. We then selected four nunatak and rock ridge sites within the scenes, and adjusted the other image DEMs to match within $\pm 5 \mathrm{~m}$ the values derived from the 2006 image over these areas. The maximum vertical adjustment required was $20 \mathrm{~m}$. Random errors in these elevation data are large over the glacier surface (up to several tens of metres), so smoothing of the data by low-pass filtering and manual editing was conducted. Our spatial smoothing scale for the DEMs was $600 \mathrm{~m}$. We estimate the error in the filtered and elevation-adjusted data to be $\pm 10 \mathrm{~m}$ based on the range of values for stationary features (rock outcrops, stable ice) in the images after corrections and filtering.

\section{Glacier surface flow velocity}

We derived glacier surface velocities using the Channel 3 nadir images from the same eight Level 1B ASTER image datasets as we used for elevation mapping (Table 1). We measured ice velocities in six sequential image pairs. We coregistered the pairs of images, separated by 81-1024 days, using the ENVI image-to-image co-registration tool. Residuals of the co-registration, using 10-20 geo-registration points, were typically $\sim 1$ pixel, or $15 \mathrm{~m}$. The IMCORR feature-tracking software distributed by the US National Snow and Ice Data Center (NSIDC; http://nsidc.org/data/ velmap/imcorr.html; Scambos and others, 1992) provided surface speeds. Vector generation from IMCORR was difficult in some images because of the absence of, or small scale of, surface features (e.g. crevasses finer than $15 \mathrm{~m}$ ) and because of sharp-edged albedo variations associated with surface melt and ablation. We limit vector data to regions where features remain relatively unchanged between the two satellite scenes, except for motion. For example, significantly different crevasse patterns appeared between scene acquisitions in some pairs that could not be correlated. This limitation reduced the areas where velocities could be extracted, due to the rapid pace of ice-dynamic changes for Röhss Glacier. The total number of accepted vectors extracted over the glacier trunk after both computer and manual editing ranged from 80 to 380 for the image pairs. Errors in the IMCORR-derived velocities vary as a function of the time between scene pairs, but range from 0.02 to $0.28 \mathrm{~m} \mathrm{~d}^{-1}$. These data are available from NSIDC at http://nsidc.org/agdc/acap. Centre-line flow data were generated by plotting all the vectors within an 80pixel $(1200 \mathrm{~m})$ swath centred along a manually estimated centre line for the glacier, based on the visible longitudinal surface structures on the glacier.

\section{Ice thickness}

We investigated ice thickness on Röhss Glacier in January 2010 using a monopulse radio-echo sounding system that combines a GPR Impulse Generator by Kentech Instruments Ltd with $5 \mathrm{MHz}$ centre-frequency antennas and a National Instruments digital USB oscilloscope as receiver and digitizer. The signals were processed using standard gains and bandpass filtering $(2.5-10 \mathrm{MHz})$ using Matlab $^{\mathrm{TM}}$ (including use of Matlab ${ }^{\mathrm{TM}}$ code developed by Tzanis, 2006).

During the radar survey, a dual-frequency GPS receiver was set up near the centre line of the glacier and run for 5 hours. The data were processed against a nearby temporary base station $(\sim 1 \mathrm{~km})$ using the kinematic baseline processing tool, track, developed at the Massachusetts Institute of Technology (Chen, 1999).

\section{THE PRINCE GUSTAV ICE SHELF AND ITS TRIBUTARY GLACIERS IN FEBRUARY 1988}

We interpreted the structural features of the PGIS prior to its collapse (Fig. 1) using Landsat 4/5 TM images acquired on 29 February 1988 and 9 February 1990. At that time, the ice shelf was fed by two main flow units (glacier trunks). The first flow unit formed the western and central area of the PGIS ('Area a' in Fig. 1a), which was fed by Sjögren Glacier on the Antarctic Peninsula. Large rifts (drawn in detail in Fig. 1b) were present on the ice-shelf surface in this area. Splaying crevasses marked the area where Sjögren Glacier entered the ice shelf.

North of the Sjögren Glacier flow unit was an area of ice shelf in Prince Gustav Channel which appears to be disconnected from active flow from Sjögren Glacier ('Area b' in Fig. 1a). Here the ice shelf was composed of fast ice with blocks of calved glacier ice filling the 'rift' areas. These rifts and associated open areas were developed parallel 


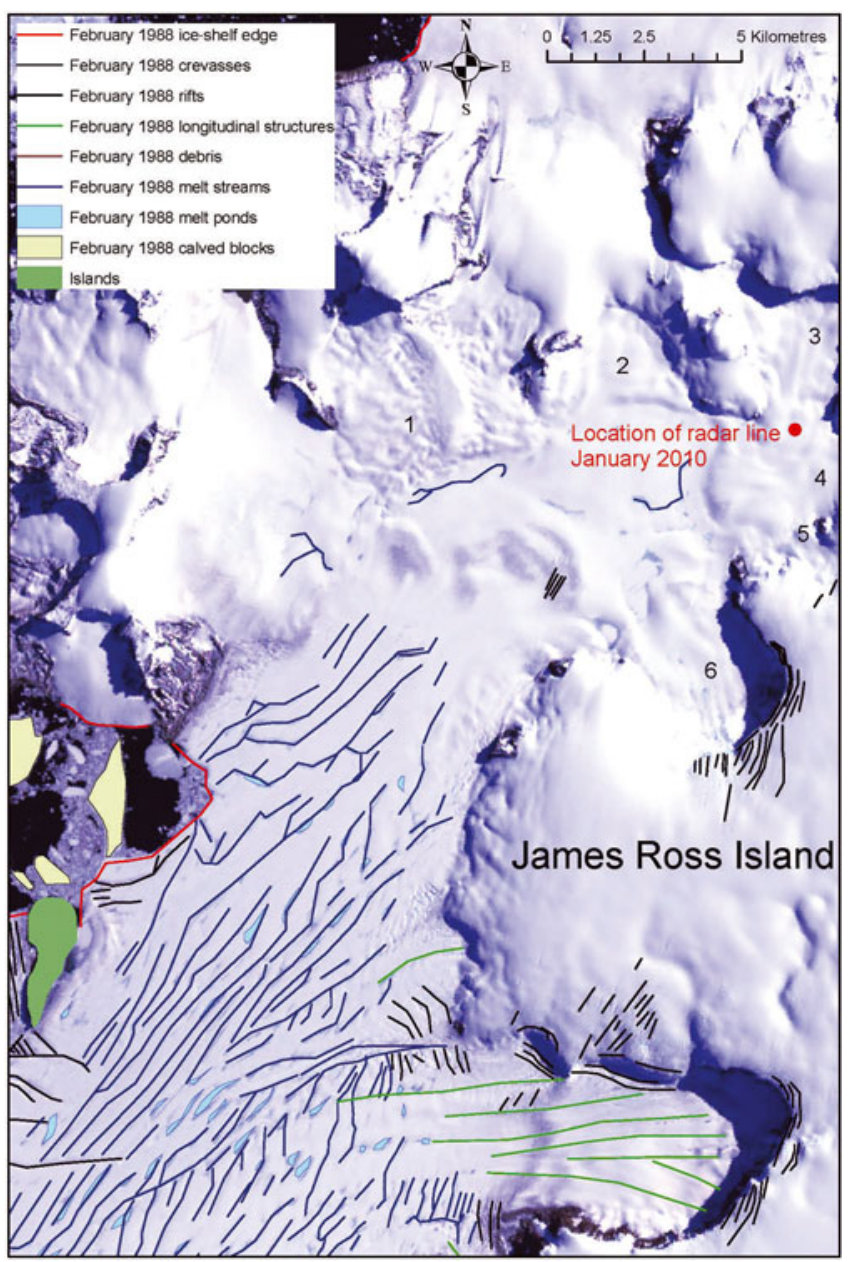

Fig. 2. Portion of Landsat 4/5 TM image showing Röhss Glacier, James Ross Island, in 1988 when it was a tributary to the PGIS. Numbers 1-6 refer to individual cirque basins discussed in the text. The location of the radar line presented in Figure 7 is indicated.

to longitudinal surface structures advected from the main trunk of Sjögren Glacier (Fig. 1b). The presence of meltwater and calved blocks within these areas indicates that the ice shelf was already very thin in 1988. Calving from the northern margin of this area of the ice shelf was also evident.

The second flow unit formed the eastern area of the ice shelf, which was fed by tributary cirque glaciers originating on James Ross Island ('Area c' in Fig. 1a; mapped in detail in Fig. 1b) and flowed through Röhss Bay (Fig. 2). Longitudinal surface structures and the orientation of surface melt streams indicate that ice flow from these cirques combined to feed the southeastern corner of the PGIS. A zone of heavy crevassing existed at the junction between this flow unit and the Sjögren Glacier flow unit (Fig. 1b). A sharp change in the orientation of crevasses and surface meltwater features also occurred at this junction, which can be traced from Persson Island all the way to the ice-shelf edge. We infer from this, and the pattern of flow of meltwater streams on the ice-shelf surface, that at this time Röhss Glacier was thicker than Sjögren Glacier.

\section{LONG-TERM GLACIER RESPONSE}

\section{Recession of tributary glaciers in Röhss Bay between January 2001 and March 2009}

Nine satellite images (Terra ASTER scenes acquired in January 2001, January 2002, December 2002, February
2004, November 2005, February 2006, December 2006, December 2008 and March 2009; Table 1) were used to document the recession of Röhss Glacier following the collapse of the PGIS (Fig. 3). This sequence covers the period from 6 to 14 years following ice-shelf removal and therefore provides information about long-term glacier response. These images reveal dramatic changes in this glacier, demonstrating that the glacier receded rapidly during its transition from ice-shelf tributary to tidewater calving glacier. The images also indicate a somewhat irregular pace of retreat, with accelerations of area loss, elevation loss and flow following major calving episodes.

Röhss Glacier is fed from a composite cirque composed of at least six individual cirque basins, or flow units, numbered 1-6 in Figure 3. At the start of the sequence, in January 2001, all six flow units combined to form a single calving front in Röhss Bay (Fig. 3a). Nearly 2 years later, in December 2002, the front of the glacier had receded by $7 \mathrm{~km}$ but continued to form a single calving front (Fig. 3b). Glacier recession slowed between January 2002 and November 2005 (Fig. 3c), before increasing again between November 2005 and December 2006 (Fig. 3d). By November 2005 the glacier had receded to the extent that flow unit 1 had become separated from the other five flow units (Fig. 3d). Large rifts were visible behind the calving front in flow units 4-6. These rifts later defined the position of the calving front in February 2006 (Fig. 4). In all images after December 2002, iceberg calving is indicated by the presence of numerous icebergs and brash ice (accumulations of floating ice made up of fragments not more than $2 \mathrm{~m}$ across) immediately in front of the calving cliff (e.g. Fig. 3c).

The overall recession history of Röhss Glacier and measured distances and area loss are shown in Figure 5. Calculated rates of centre-line glacier recession and area losses over the same time period are presented in Table 2. The data show that retreat was not uniform with time; rapid retreat and area loss marked the first year of the image series (2001), and again between late 2004 and early 2006. The ice front advanced slightly ( $200 \mathrm{~m}$ ) between February 2006 and December 2006, before receding $1244 \mathrm{~m}$ between December 2006 and December 2008, and $470 \mathrm{~m}$ between December 2008 and March 2009.

\section{Ice-dynamical changes in tributary glaciers in Röhss Bay between January 2001 and March 2009}

\section{(a) Surface elevation changes}

We extracted ice surface elevation profiles along the centre line of Röhss Glacier from the ASTER DEMs (Fig. 6a). The eight centre-line profiles show a trend of general elevation loss between January 2001 and March 2009. Total loss of elevation between January 2001 and December 2008 is up to $150 \mathrm{~m}$ in the upper basin (Fig. 6). As with the area and icefront retreats, the elevation loss appears to have been highest during 2001-02 and 2005-early 2006. The last two profiles indicate stabilization, with a near-zero change in surface elevation between December 2008 and March 2009.

\section{(b) Surface speed changes}

Data for the centre-line surface speeds (Fig. 6b and c) are limited to areas where features can successfully be tracked from image to image because of the large surface changes that occur between image pairs (partly ice-dynamic because of the development of new crevasse regions or changes in the crevassed areas from image to image; partly because of 
a

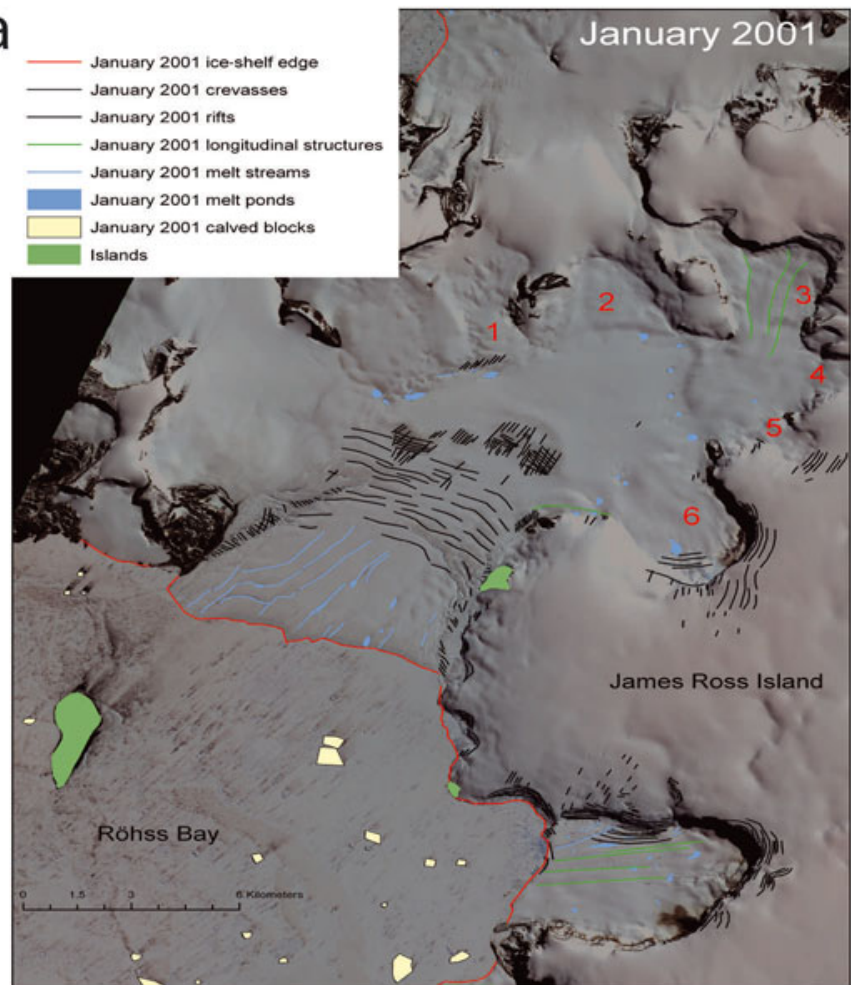

C

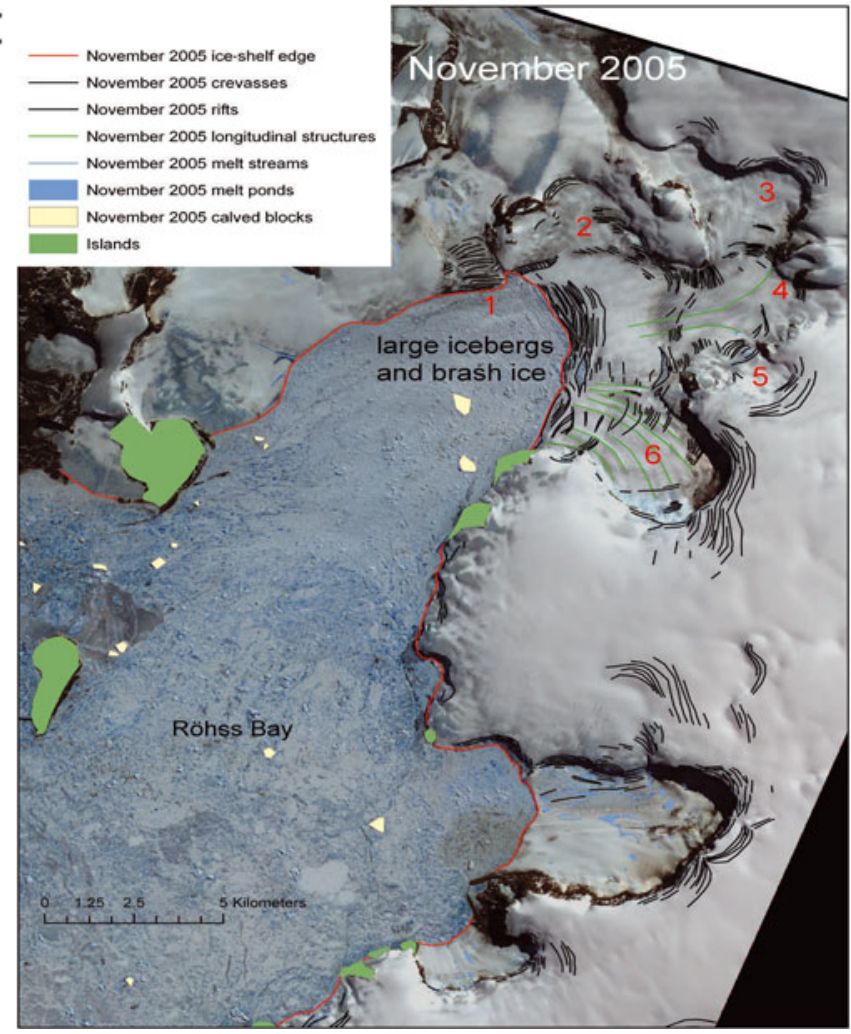

b

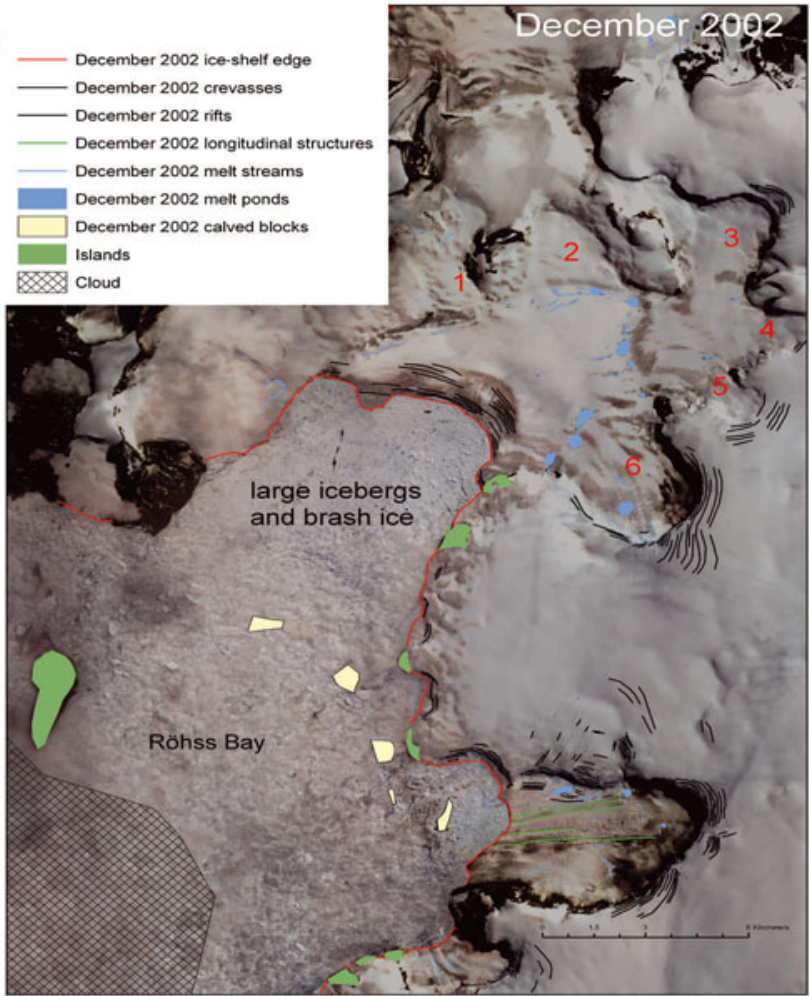

d

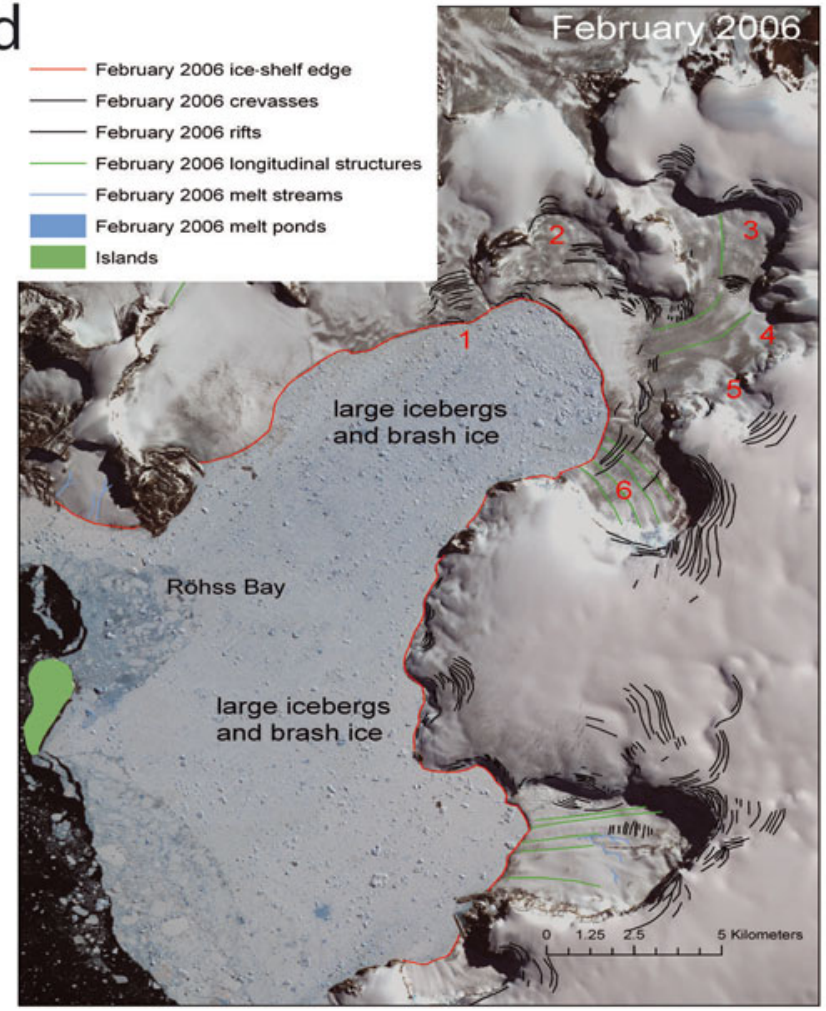

Fig. 3. Time series of changes in Röhss Glacier, a former tributary to the PGIS. Interpretations are superimposed on ASTER images from (a) January 2001, (b) December 2002, (c) November 2005 and (d) February 2006.

the climate, as the summer images often contain areas with surface melt or saturated firn regions that disrupt the imageto-image correlation mapping). The extracted speeds from the vectors for the main flowline (40 pixels, or $600 \mathrm{~m}$, to either side of the line) are plotted in Figure 6c. This relatively narrow band of extracted speeds provides a good representation of the centre flow rate, with little effects of marginal shear or tributary flow. These data show some large speed increases (e.g. from $0.1 \mathrm{md}^{-1}$ in the period 10 November 2005 to 23 February 2006 to $0.9 \mathrm{~m} \mathrm{~d}^{-1}$ in the period 13 December 2008 to 3 March 2009 in the uppermost reaches of the glacier). We note that the speed 


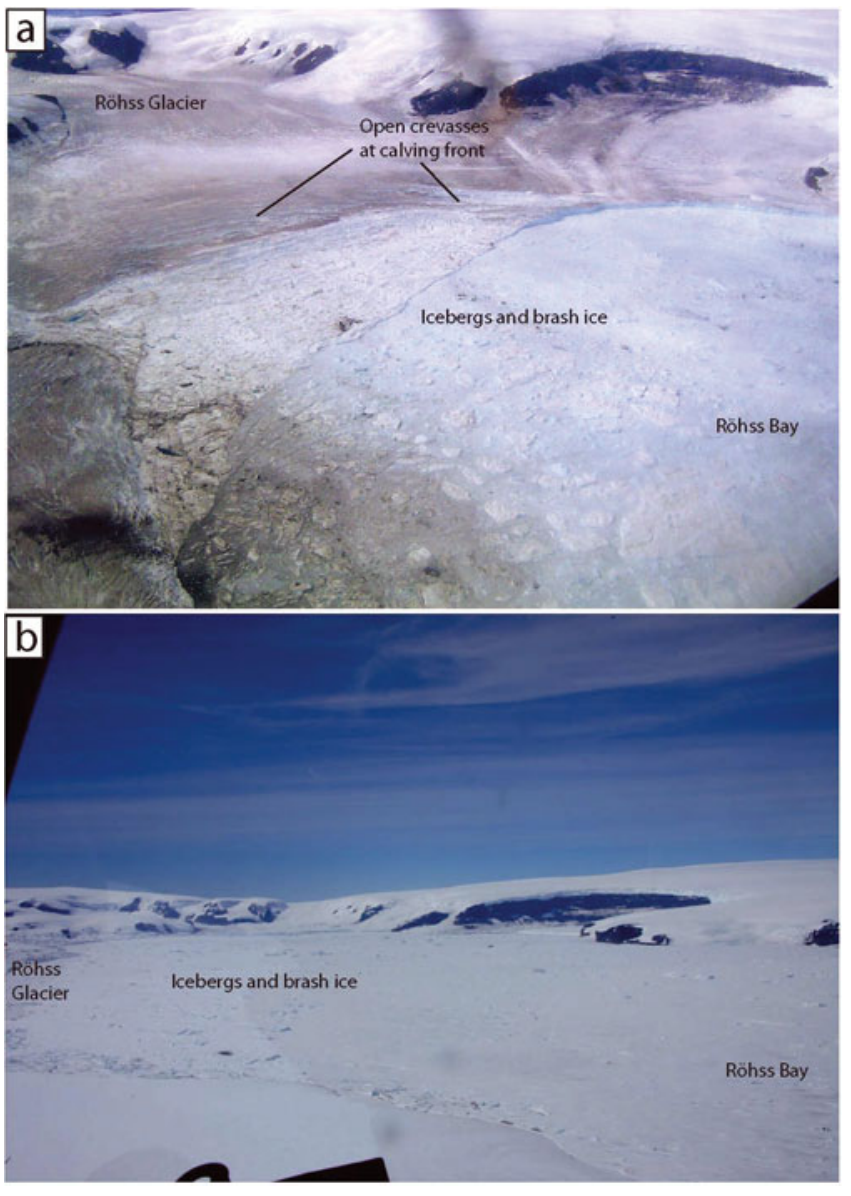

Fig. 4. (a) Oblique aerial photo of rapid tidewater calving in the lower trunk area in Röhss Bay taken on 11 February 2006. Aircraft location $\sim 64.069^{\circ} \mathrm{S}, 58.246^{\circ} \mathrm{W}$, altitude $\sim 1000 \mathrm{~m}$. (Photograph by T.A. Scambos.) (b) Similar-perspective photograph taken from helicopter on 11 January 2010. (Photograph by M. Truffer.)

increase is not monotonic; in the upper glacier, surface speeds decreased between 2002 and 2006, before increasing again in recent years.

During a brief field visit in January 2010, a speed of $0.61 \pm 0.13 \mathrm{~m} \mathrm{~d}^{-1}$ was measured over a 5 hour period, with the GPS near the centre line and at the uppermost reaches of Röhss Glacier (Fig. 2). This flow speed high up in the glacier indicates further acceleration during the 2009/10 austral summer, although this could be a seasonal effect. At this a

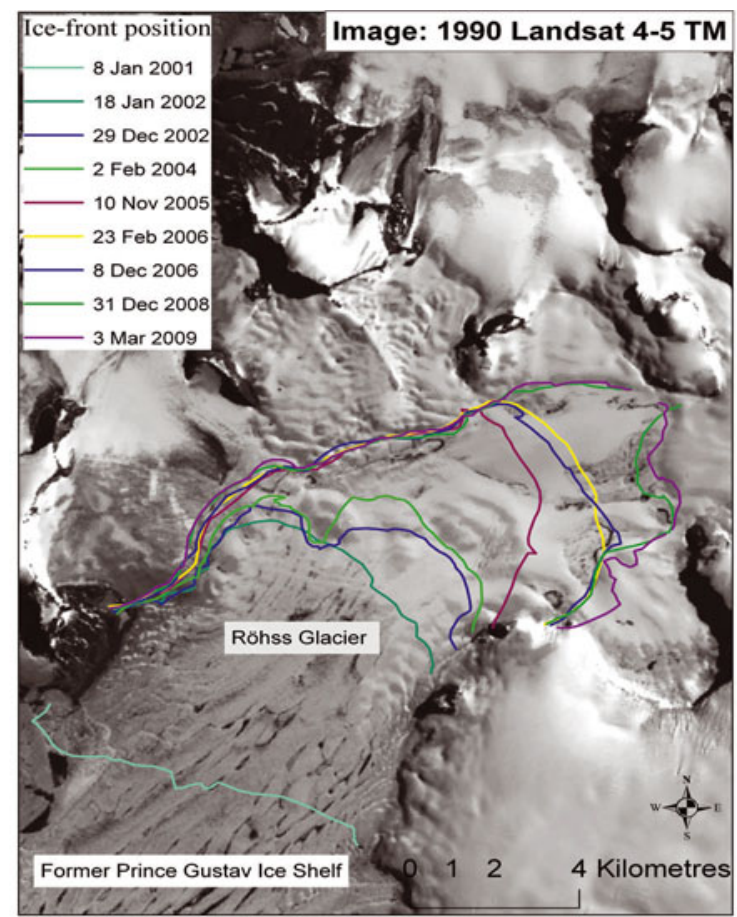

b

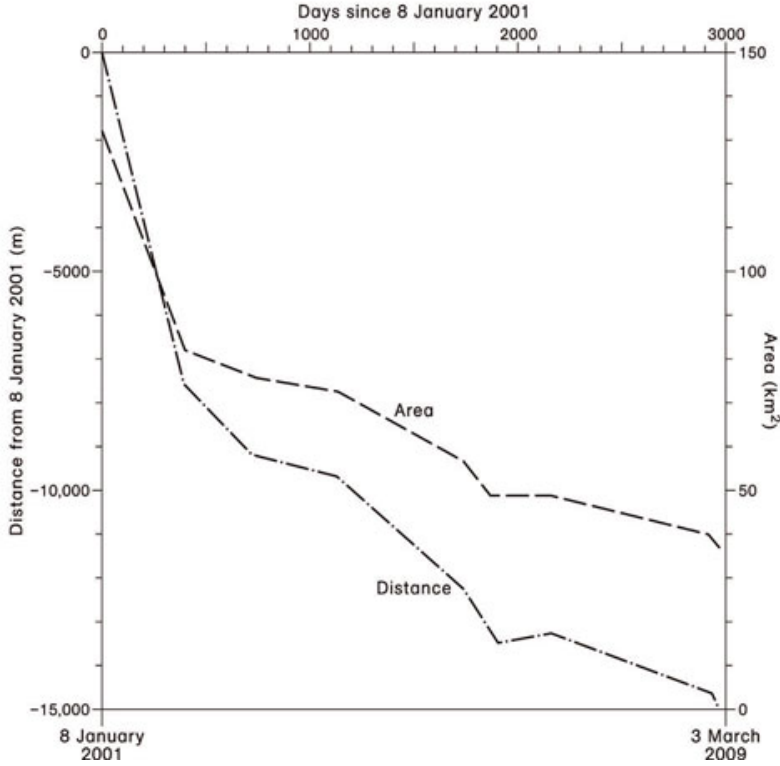

Fig. 5. (a). Overall pattern of recession of Röhss Glacier between 2001 and 2009 superimposed on 1990 Landsat 4/5 TM image. (b) Frontal recession and area loss for the glacier in the same period.

Table 2. Calculated frontal recession, corresponding rates of glacier recession, area changes and remaining area for Röhss Glacier between 8 January 2001 and 3 March 2009

\begin{tabular}{|c|c|c|c|c|c|c|}
\hline From (date) & To (date) & No. of days & $\begin{array}{l}\text { Ice-front recession } \\
\text { m }\end{array}$ & $\begin{array}{l}\text { Recession rate } \\
\mathrm{m} \mathrm{d}^{-1}\end{array}$ & $\begin{array}{c}\text { Area lost } \\
\mathrm{km}^{2}\end{array}$ & $\begin{array}{c}\text { Remaining area } \\
\mathrm{km}^{2}\end{array}$ \\
\hline 8 Jan $2001^{*}$ & 18 Jan 2002 & 375 & 7514 & 20.04 & 50 & 82 \\
\hline 18 Jan 2002 & 29 Dec 2002 & 345 & 1609 & 4.67 & 6 & 76 \\
\hline 29 Dec 2002 & 2 Feb 2004 & 400 & 332 & 0.83 & 3 & 73 \\
\hline 2 Feb 2004 & 10 Nov 2005 & 647 & 2785 & 4.30 & 16 & 57 \\
\hline 10 Nov 2005 & 23 Feb 2006 & 105 & 1166 & 11.1 & 8 & 49 \\
\hline 23 Feb 2006 & 8 Dec 2006 & 288 & -200 & -0.69 & $\sim 0$ & 49 \\
\hline 8 Dec 2006 & 13 Dec 2008 & 754 & 1244 & 1.65 & 9 & 40 \\
\hline 13 Dec 2008 & 3 Mar 2009 & 62 & 470 & 7.58 & 3 & 37 \\
\hline
\end{tabular}

*Röhss area on 8 January 2001 was $132 \mathrm{~km}^{2}$. 

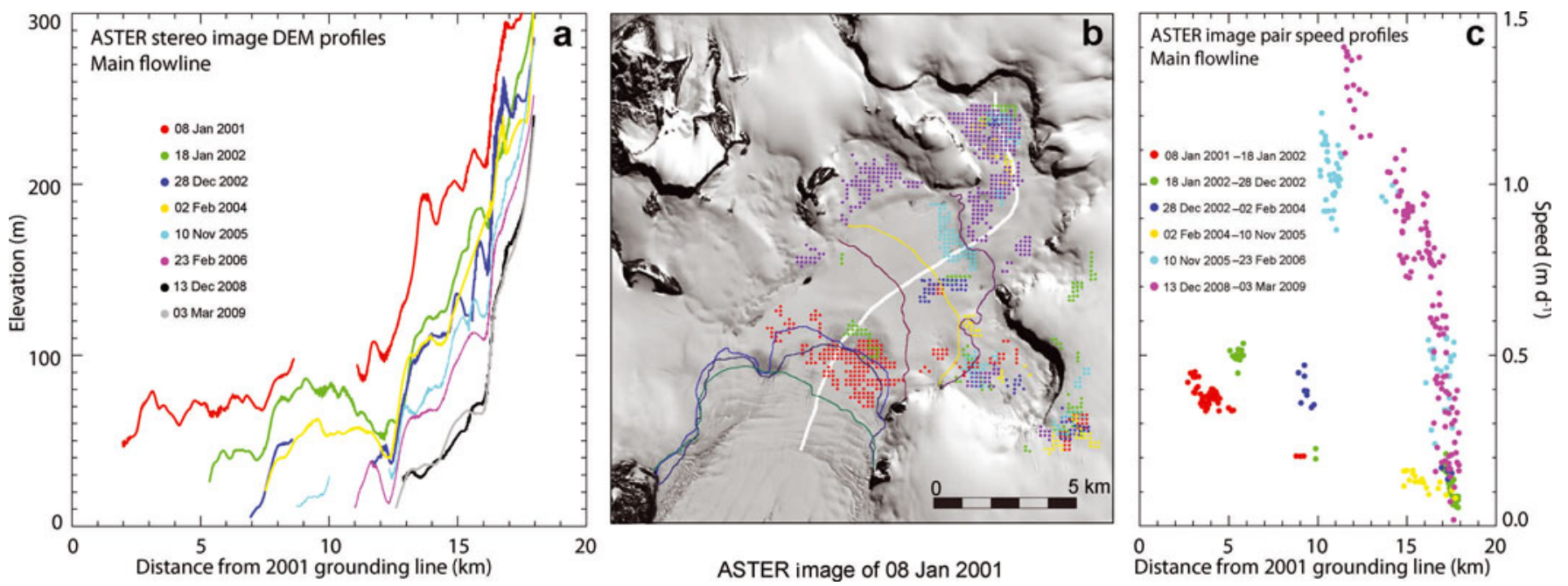

Fig. 6. (a). Elevation profiles extracted along the main flowline of Röhss Glacier from the ASTER stereo-image DEMs. (b) Surface speed measurement points on Röhss Glacier retrieved from six ASTER image pairs. The curvilinear flowline is the path for the elevation-change data and the surface-speed profile data presented in (c). Key to colours of the ice fronts is the same as Figure 5. (c) Glacier surface speeds extracted from the vectors for the main flowline of Röhss Glacier (data are for 40 pixels, or $600 \mathrm{~m}$, to either side of the line).

location, near the centre of the glacier, the ice thickness was $150 \mathrm{~m}$. With an estimated slope of $3^{\circ}$, the deformational velocity for an infinitely extended plate of temperate ice is only $0.015 \mathrm{~m} \mathrm{~d}^{-1}$ (using Glen's flow law with parameters as given by Paterson, 1994). This indicates that the flow of the glacier at this point is almost entirely due to basal motion.

\section{(c) Ice thickness}

Ice thickness data come from a radar line collected on Röhss Glacier in January 2010 around $64.0777^{\circ} \mathrm{S}, 57.9970^{\circ} \mathrm{W}$. These data show a very strong consistent reflector around $150 \mathrm{~m}$ depth (using a wave speed of $168 \mathrm{~m} \mathrm{~ms}^{-1}$ ), interpreted as the glacier bed (Fig. 7). The second reflector below the bed reflector is interpreted as an off-axis reflector from a crevasse.

\section{DISCUSSION}

\section{Structural glaciology}

The structural discontinuities and rift zones visible between flow units in the 1988 Landsat image of the PGIS indicate that the ice shelf may already have begun to disintegrate at least 7 years prior to its ultimate demise. This assertion is supported by radiometric ${ }^{210} \mathrm{~Pb}$ dating of rates of sediment accumulation on the sea floor beneath the former ice shelf (Gilbert and Domack, 2003). These authors described coarsening-upward sediments with up to $40 \%$ sand at the surface that accumulated between 1985 and 1993, several years before break-up of the ice shelf, and concluded that rates of sediment accumulation on the sea floor doubled to quadrupled during this period. Gilbert and Domack (2003) interpreted these as the release of aeolian sediment in periodic rapid draining of small lakes and crevasses on the ice shelf before break-up, with gravel particles related to ice rafting during ice-shelf disintegration.

The discontinuities between the Röhss Glacier and Sjögren Glacier flow units also indicate that prior to collapse, the ice shelf may not have been a cohesive structure. On other Antarctic Peninsula ice shelves that are fed by multiple tributary glaciers (e.g. Larsen B, King George $\mathrm{VI}$ ), individual flow units tend to be sutured together to form cohesive ice shelves. If the PGIS was not a cohesive ice shelf, this may provide evidence that it has collapsed and regrown in the recent geological past, perhaps in a cyclic fashion. Indeed, ice-rafted debris in marine cores shows that it retreated at least once in mid-Holocene times (Pudsey and Evans, 2001). The PGIS was formed by glaciers that merged head-on across a strait rather than a bay. This geometry results in an ice shelf with a compressive stress regime at the centre contact between the two glaciers and allows for ocean currents to flow underneath. This geometry, therefore, may lead to an ice shelf which is less cohesive and more sensitive to collapse.

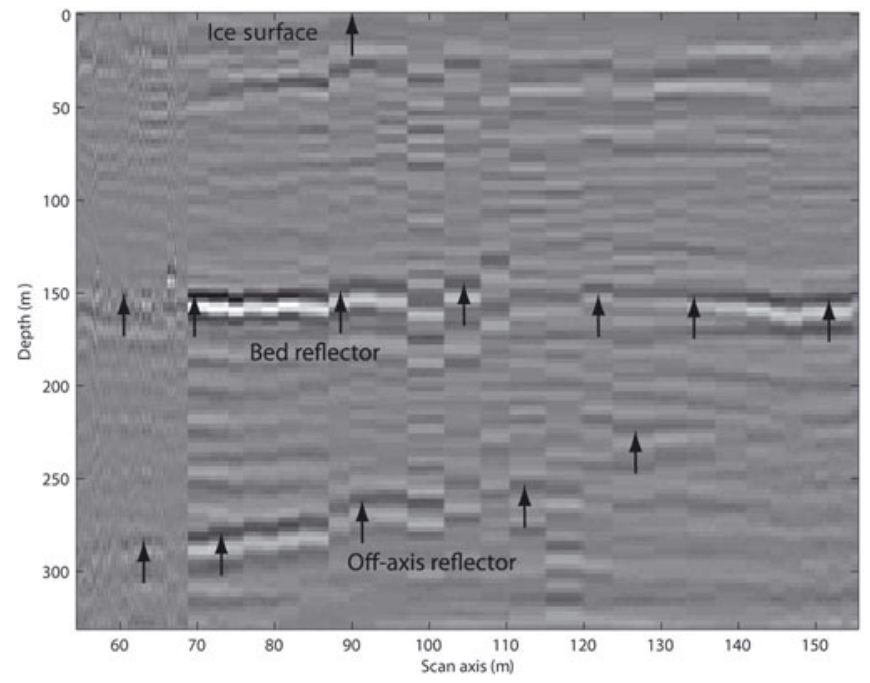

Fig. 7. Radar line from profile collected near mid-glacier on Röhss Glacier in January 2010. These data are not corrected for surface topography along the profile. The strong, consistent reflector that averages $\sim 150 \mathrm{~m}$ depth is interpreted as the glacier bed. The location of the radar line is indicated in Figure 2. 
a

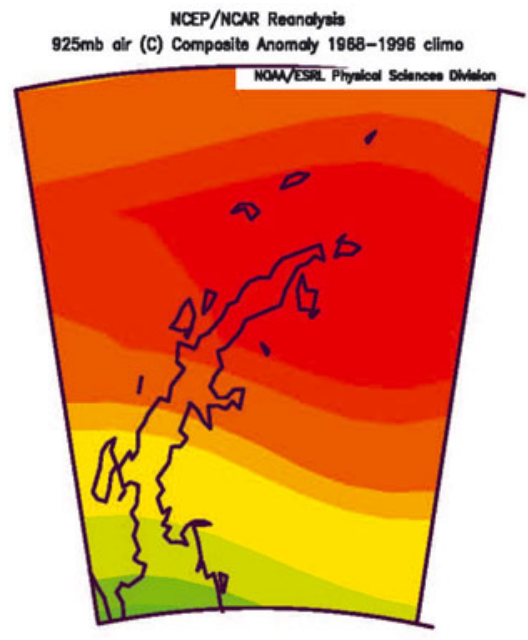

Nov to Mor: 1995 to 1995 minue 1979 to 2010

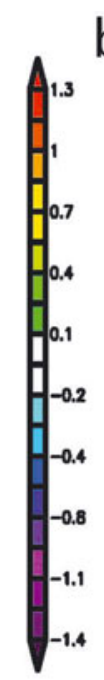

NCEP/NCWR Roonotysis
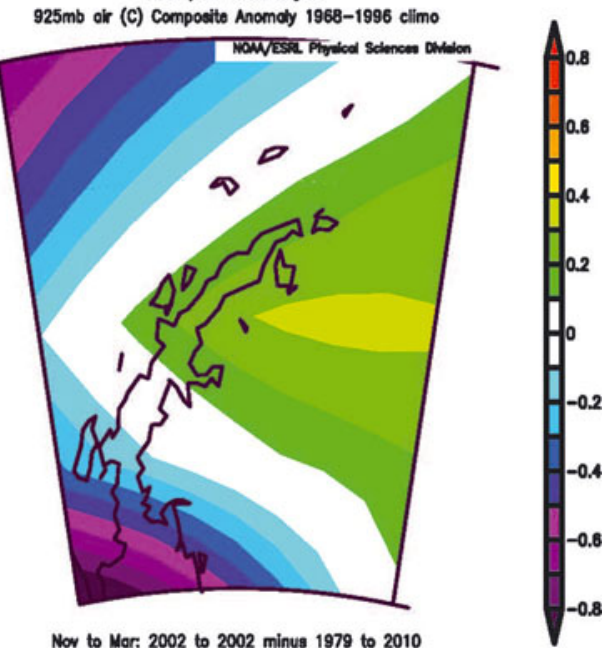

C
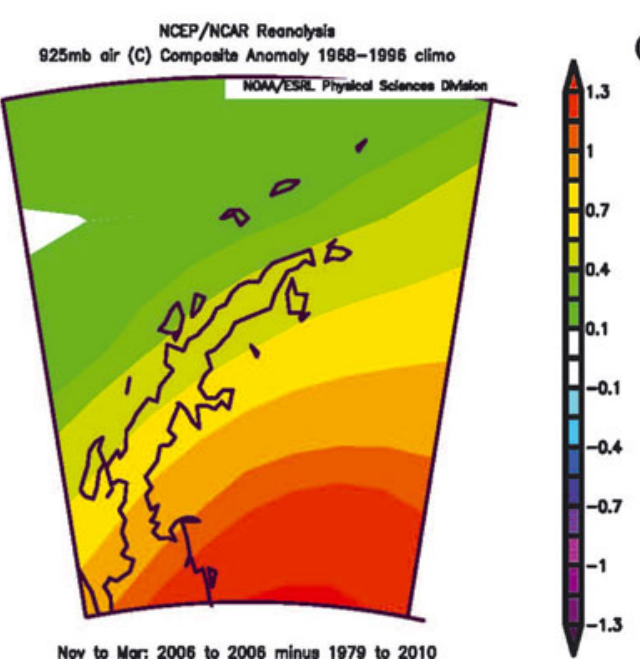

d

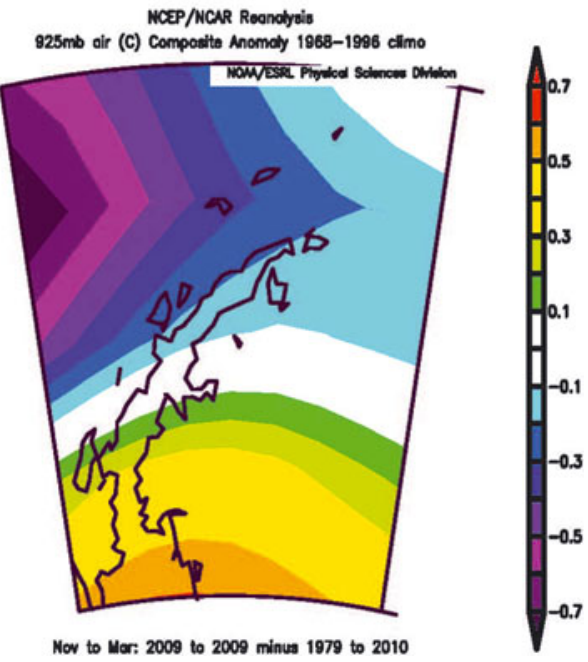

Fig. 8. Mean summer temperature anomaly at 925 mbar for the Antarctic Peninsula from NCEP/NCAR Reanalysis for (a) 1995 (the year of the PGIS collapse), (b) 2002, (c) 2006 and (d) 2009. Note that 1995, 2002 and 2006 were relatively warm years, coinciding with rapid glacier recession (Fig. 5), whereas 2009 was a relatively cool year, coinciding with a stabilization in the rate of glacier recession.

\section{Ice-shelf and glacier dynamics and the transition to tidewater calving}

Previous studies on the Antarctic Peninsula have shown that ice-shelf removal results in the thinning, acceleration and surging of tributary glaciers. Scambos and others (2004) derived glacier speeds from Landsat 7 images that show a two- to sixfold increase in the centre-line speed of glaciers flowing into the collapsed section of the Larsen B ice shelf. Using RADARSAT, Rignot and others (2004) found that former tributary glaciers to the ice shelf flowed eight times faster in 2003 than they did in 2000. Two former tributaries (Jorum and Crane Glaciers) accelerated twofold in early 2003 and threefold by the end of 2003. Satellite laser altimetry from ICESat indicates that the surface of another former tributary, Hektoria Glacier, lowered by up to $38 \pm 6 \mathrm{~m}$ in a 6 month period beginning 1 year after iceshelf collapse in March 2002, with similar elevation losses for Crane and Jorum Glaciers (Scambos and others, 2004).

The transition from ice-shelf tributary to tidewater glacier is an important dynamic factor. The PGIS had a compressive stress regime at its centre. The response of the tributary glaciers to the loss of the ice shelf was influenced by these compressive stresses, in contrast to the mainly tensile stresses in floating tongues of tidewater glaciers. The change in the stress situation was therefore more drastic in the case of the PGIS than it would have been for the loss of an ice shelf that is deforming under an extensional regime. Thus, we would expect glacier response to be enhanced; this might be why the duration of the acceleration and thinning is on the decadal scale. We speculate that, because calving greatly increases mass loss, it can initiate rapid and, in the short term, irreversible glacier recession in which increased ice flow leads to thinning, loss of bed traction and continued acceleration (cf. Pfeffer, 2007; Walter and others, 2010).

When tributary glaciers become tidewater glaciers they experience rapid and continued recession (up to 14 years and ongoing) following ice-shelf collapse. This suggests that tributary glaciers may respond to ice-shelf removal not only on annual but also decadal timescales. However, rapid recession will not carry on unchecked. With an ice thickness of $\sim 150 \mathrm{~m}$ at $\sim 180 \mathrm{~m}$ elevation, the bed of Röhss Glacier is above sea level at this location. If rapid recession continues, the glacier will soon become land-terminating and will no longer be subject to mass loss from calving. 


\section{Glacier recession and possible future behaviour}

The overall pattern of recession of Röhss Glacier is unsurprising given the general trend of regional glacier frontal recession across the Antarctic Peninsula (Rau and others, 2004; Cook and others, 2005). At the same time, there has been a widespread acceleration of tidewater glaciers on the Antarctic Peninsula (Pritchard and Vaughan, 2007). Iceshelf collapse on the Antarctic Peninsula has been linked to increasing atmospheric temperature and the production of surface meltwater (Scambos and others, 2000; Skvarca and others, 2004), but the punctuated recession exhibited by Röhss Glacier (Fig. 5b) is also partly explained by changes in the regional climate (Fig. 8). Data from the US National Centers for Environmental Prediction(NCEP)/US National Center for Atmospheric Research (NCAR) Reanalysis indicate that 1995, 2002 and 2006 were relatively warm years, coinciding with the initial ice-shelf collapse (1995) and with a period of rapid glacier recession between 2002 and 2006. The year 2009 was relatively cool, coinciding with possible temporary glacier stabilization.

Finally, we speculate on the future prospects for the glaciers of the Antarctic Peninsula. Since many of the former tributary glaciers of Antarctic Peninsula ice shelves are now calving glaciers, their future behaviour is governed largely by calving dynamics and not simply by external climate forcing. We speculate that the trends of glacier recession (Cook and others, 2005) and tidewater glacier acceleration (Pritchard and Vaughan, 2007) will continue because many of the former ice-shelf tributary glaciers have not yet receded to stable positions (Alley and others, 2007) and surface slope has increased, increasing driving stress. Furthermore, because glacier recession is ongoing at Röhss Glacier 14 years after the collapse of the PGIS, we also infer that the tidewater glaciers now draining into areas formerly occupied by collapsed ice shelves such as the PGIS, Larsen A and Larsen B will continue to recede for a number of years. Further monitoring of these newly formed tidewater glaciers, and the remaining Antarctic Peninsula ice shelves and their tributary glaciers, is required to ascertain their future response and potential contribution to sea-level rise (Hulbe and others, 2008; Hock and others, 2009).

\section{CONCLUSIONS}

Break-up of the PGIS began before 1988, at least 7 years before its final collapse in 1995. Röhss Glacier, a former tributary of the PGIS, neatly illustrates glacier reaction to ice-shelf removal. After the ice shelf collapsed, the glacier receded rapidly, thinned and accelerated due to the removal of the back-stress provided by the ice shelf and because of increased mass loss due to the transition to tidewater calving. Between January 2001 and March 2009 (6-14 years after collapse), the front of Röhss Glacier receded $\sim 15 \mathrm{~km}$ and lost $>70 \%$ of its area. Our data suggest that tributary glaciers respond to ice-shelf removal on annual to decadal timescales and that former ice-shelf tributary glaciers are highly sensitive to ice-shelf removal, in concurrence with other studies.

\section{ACKNOWLEDGEMENTS}

N.F.G. acknowledges financial support for this project from the US-UK Fulbright Commission and a Cooperative Institute for Research in Environmental Sciences (CIRES)
Fellowship. NASA provided no-cost access to ASTER imagery through their LP DAAC User Services. We thank two anonymous reviewers for their comments. We also acknowledge the LARISSA (LARsen Ice Shelf System, Antarctica) project for logistical support. The UK Natural Environment Research Council also provided financial support for the work (NE/F012942/1).

\section{REFERENCES}

Alley, R.B., S. Anandakrishnan, T.K. Dupont, B.R. Parizek and D. Pollard. 2007. Effect of sedimentation on ice-sheet grounding-line stability. Science, 315(5820), 1838-1841.

Braun, M., A. Humbert and A. Moll. 2009. Changes of Wilkins Ice Shelf over the past 15 years and inferences on its stability. Cryosphere, 3(1), 41-56.

Chen, G. 1999. GPS kinematic positioning for the airborne laser altimetry at Long Valley, California. (PhD thesis, Massachusetts Institute of Technology.)

Chen, J.L., C.R. Wilson, D. Blankenship and B.D. Tapley. 2009. Accelerated Antarctic ice loss from satellite gravity measurements. Nature Geosci., 2(12), 859-862.

Cook, A.J. and D.G. Vaughan. 2010. Overview of areal changes of the ice shelves on the Antarctic Peninsula over the past 50 years. Cryosphere, 4(1), 77-98.

Cook, A.J., A.J. Fox, D.G. Vaughan and J.G. Ferrigno. 2005. Retreating glacier fronts on the Antarctic Peninsula over the past half-century. Science, 308(5721), 541-544.

De Angelis, H. and P. Skvarca. 2003. Glacier surge after ice shelf collapse. Science, 299(5612), 1560-1562.

Doake, C.S.M. and D.G. Vaughan. 1991. Rapid disintegration of the Wordie Ice Shelf in response to atmospheric warming. Nature, 350(6316), 328-330.

Gilbert, R. and E.W. Domack. 2003. Sedimentary record of disintegrating ice shelves in a warming climate, Antarctic Peninsula. Geochem. Geophys. Geosyst., 4(4), 1038. (10.1029/2002GC000441.)

Glasser, N.F. and T.A. Scambos. 2008. A structural glaciological analysis of the 2002 Larsen B ice-shelf collapse. J. Glaciol., 54(184), 3-16.

Glasser, N. and 7 others. 2009. Surface structure and stability of the Larsen C ice shelf, Antarctic Peninsula. J. Glaciol., 55(191), 400-410.

Hock, R., M. de Woul and V. Radiá. 2009. Mountain glaciers and ice caps around Antarctica make a large sea-level rise contribution. Geophys. Res. Lett., 36(7), L07501. (10.1029/ 2008GL037020.)

Howat, I.M., I. Joughin, M. Fahnestock, B.E. Smith and T. Scambos. 2008. Synchronous retreat and acceleration of southeast Greenland outlet glaciers 2000-2006: ice dynamics and coupling to climate. J. Glaciol., 54(187), 646-660.

Hulbe, C.L., T.A. Scambos, T. Youngberg and A.K. Lamb. 2008. Patterns of glacier response to disintegration of the Larsen B ice shelf, Antarctic Peninsula. Global Planet. Change, 63(1), 1-8.

Humbert, A. and M. Braun. 2008. Correspondence. The Wilkins Ice Shelf, Antarctica: break-up along failure zones. J. Glaciol., 54(188), 943-944.

Humbert, A., T. Kleiner, C.-O. Mohrholz, C. Oelke, R. Greve and M.A. Lange. 2009. A comparative modeling study of the Brunt Ice Shelf/Stancomb-Wills Ice Tongue system, East Antarctica. J. Glaciol., 55(189), 53-65.

Joughin, I., W. Abdalati and M.A. Fahnestock. 2004. Large fluctuations in speed on Greenland's Jakobshavn Isbræ glacier. Nature, 432(7017), 608-610.

Luckman, A., T. Murray, R. de Lange and E. Hanna. 2006. Rapid and synchronous ice-dynamic changes in East Greenland. Geophys. Res. Lett., 33(3), L03503. (10.1029/2005GL025428.)

Paterson, W.S.B. 1994. The physics of glaciers. Third edition. Oxford, etc., Elsevier. 
Pfeffer, W.T. 2007. A simple mechanism for irreversible tidewater glacier retreat. J. Geophys. Res., 112(F3), F03S25. (10.1029/ 2006JF000590.)

Pritchard, H.D. and D.G. Vaughan. 2007. Widespread acceleration of tidewater glaciers on the Antarctic Peninsula. J. Geophys. Res., 112(F3), F03S29. (10.1029/2006JF000597.)

Pudsey, C.J. and J. Evans. 2001. First survey of Antarctic sub-ice shelf sediments reveals mid-Holocene ice shelf retreat. Geology, 29(9), 787-790.

Rack, W., C.S.M. Doake, H. Rott, A. Siegel and P. Skvarca. 2000. Interferometric analysis of the deformation pattern of the northern Larsen Ice Shelf, Antarctic Peninsula, compared to field measurements and numerical modeling. Ann. Glaciol., 31, 205-210.

Rau, F. and 8 others. 2004. Variations of glacier frontal positions on the northern Antarctic Peninsula. Ann. Glaciol., 39, 525-530.

Rignot, E., G. Casassa, P. Gogineni, W. Krabill, A. Rivera and R. Thomas. 2004. Accelerated ice discharge from the Antarctic Peninsula following the collapse of Larsen B ice shelf. Geophys. Res. Lett., 31(18), L18401. (10.1029/2004GL020697.)

Rignot, E. and 9 others. 2005. Recent ice loss from the Fleming and other glaciers, Wordie Bay, West Antarctic Peninsula. Geophys. Res. Lett., 32(7), L07502. (10.1029/2004GL021947.)

Rott, H., W. Rack, T. Nagler and P. Skvarca. 1998. Climatically induced retreat and collapse of northern Larsen Ice Shelf, Antarctic Peninsula. Ann. Glaciol., 27, 86-92.

Rott, H., W. Rack, P. Skvarca and H. De Angelis. 2002. Northern Larsen Ice Shelf, Antarctica: further retreat after collapse. Ann. Glaciol., 34, 277-282.

Scambos, T.A., M.J. Dutkiewicz, J.C. Wilson and R.A. Bindschadler. 1992. Application of image cross-correlation to the measurement of glacier velocity using satellite image data. Remote Sens. Environ., 42(3), 177-186.

Scambos, T.A., C. Hulbe, M. Fahnestock and J. Bohlander. 2000. The link between climate warming and break-up of ice shelves in the Antarctic Peninsula. J. Glaciol., 46(154), 516-530.

Scambos, T., C. Hulbe and M. Fahnestock. 2003. Climate-induced ice shelf disintegration in the Antarctic Peninsula. In Domack, E.W., A. Burnett, A. Leventer, P. Conley, M. Kirby and
R. Bindschadler, eds. Antarctic Peninsula climate variability: a historical and paleoenvironmental perspective. Washington, DC, American Geophysical Union, 79-92. (Antarctic Research Series 79.)

Scambos, T.A., J.A. Bohlander, C.A. Shuman and P. Skvarca. 2004. Glacier acceleration and thinning after ice shelf collapse in the Larsen B embayment, Antarctica. Geophys. Res. Lett., 31(18), L18402. (10.1029/2004GL020670.)

Scambos, T.A., T.M. Haran, M.A. Fahnestock, T.H. Painter and J. Bohlander. 2007. MODIS-based Mosaic of Antarctica (MOA) data sets: continent-wide surface morphology and snow grain size. Remote Sens. Environ., 111(2-3), 242-257.

Scambos, T. and 7 others. 2009. Ice shelf disintegration by plate bending and hydro-fracture: satellite observations and model results of the 2008 Wilkins ice shelf break-ups. Earth Planet. Sci. Lett., 280(1-4), 51-60.

Shepherd, A., D. Wingham, T. Payne and P. Skvarca. 2003. Larsen ice shelf has progressively thinned. Science, 302(5646), 856859.

Skvarca, P., H. De Angelis and A.F. Zakrajsek. 2004. Climatic conditions, mass balance and dynamics of Larsen B ice shelf, Antarctic Peninsula, prior to collapse. Ann. Glaciol., 39, 557562.

Thomas, R.H., T.J.O. Sanderson and K.E. Rose. 1979. Effect of climatic warming on the West Antarctic ice sheet. Nature, 277(5695), 355-358.

Tzanis, A. 2006. MATGPR: a freeware MATLAB package for the analysis of common-offset GPR data. Geophys. Res. Abstr., 8, EGU06-A-09488.

Van den Broeke, M. 2005. Strong surface melting preceded collapse of Antarctic Peninsula ice shelf. Geophys. Res. Lett., 32(12), L12815. (10.1029/2005GL023247.)

Vaughan, D.G. and C.S.M. Doake. 1996. Recent atmospheric warming and retreat of ice shelves on the Antarctic Peninsula. Nature, 379(6563), 328-331.

Walter, F., S. O'Neel, D.E. McNamara, T. Pfeffer, J. Bassis and H.A. Fricker. 2010. Iceberg calving during transition from grounded to floating ice: Columbia Glacier, Alaska. Geophys. Res. Lett., 37(15), L15501. (10.1029/2010GL043201.)

MS received 11 August 2010 and accepted in revised form 8 February 2011 